Research Article

\title{
"Knowledge in pieces" view: conceptual understanding analysis of pre-service physics teachers on direct current resistive electrical circuits
}

\author{
Nehru1, Cicyn Riantoni2*, Dian Pertiwi Rasmiz, Wawan Kurniawan4, Iskandar5 \\ Universitas Jambi, Department of Physics Education, Indonesia
}

\section{Article Info}

Received: 21 January 2020

Revised: 01 May 2020

Accepted: 08 May 2020

Available online: 15 June 2020

Keywords:

Conceptual understanding

Direct current resistive electrical

Circuits

Knowledge in piece

2149-360X/ C 2020 The Authors. Published by Young Wise Pub. Ltd This is an open access article under the CC BY-NC-ND license

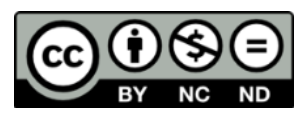

\begin{abstract}
In agreement with problem-solving skills, identifying conceptual understanding is an supreme topic in physics. The purpose of this study was to analyze the conceptual understanding of pre-service physics teachers, on direct current based electric material "Knowledge in Piece" Theory. The study used a mixed-method approach with an explanatory model with 148 pre-service physics teachers at Jambi University, Indonesia. Data were collected using concept understanding tests and interviews. The students were given a concept understanding test using reasoned multiple-choice question developed to find out the understanding of student concepts, while unstructured interviews were conducted to confirm student answers that were not clear. Data analysis was done by using a rubric which has developed based on the possible reasons for student' answer to the concept of direct current electricity. The result of this study showed that understanding the concept of students in direct current electricity material is still substandard, it is shown from the study data that only 6 people out of 148 students can activate the concept properly and entirely. The findings showed that students' understanding is still in the form of concept pieces. Students are not able to connect concepts appropriately. When students are asked about sub-material, they show a clear understanding, but when the problem is given as a whole, students are not able to connect concepts to the sub-material that they understand correctly. The results were interpreted that the students' understanding had not been coupled coherently, thus consequently that the less dominant resource would be delayed activating than the more dominant resource.
\end{abstract}

\section{To cite this article:}

Nehru., Riantoni, C., Rasmi, D.P., Kurniawan, W., \& Iskandar. (2020). "Knowledge in pieces" view: conceptual understanding analysis of pre-service physics teachers on direct current resistive electrical circuits. Journal for the Education of Gifted Young Scientists, 8(2), 723-730. DOI: http://dx.doi.org/10.17478/jegys.695358

\section{Introduction}

In this era of technological innovations, it is seen that countries that attach importance to science and technology are developing rapidly and giving direction to science (Kalayci \& Cockun, 2020). In this context, understanding the concepts in learning science is very important to avoid misconceptions in students and is one of the requirements in achieving success in learning science (Dewi \& Andi, 2016). Understanding concepts is one of the keys to success in studying science, especially physics because physics has a close relationship with facts, concepts, principles, laws, and processes (Elisa et al. 2017; Oktalia et al. 2017). Besides, physics learning should be able to focus the students to master concepts by experiencing directly (Yuberti et al. 2019).

Students who came to campus is not empty. Instead, the student's head is already full of experience and knowledge related to the lessons to be learned (Mosik \& Maulana, 2010). Before acquire learning in the classroom, students have their conception as a result of interpretation of the concepts of an object or phenomenon never observed. This

1 Lecturer, Physics Education Department, Universitas Jambi, Indonesia, Email: nehru@unja.ac.id ORCID No: 0000-0002-1166-5732

2 Lecturer, Physics Education Department, Universitas Jambi, Indonesia, Email: cicvnriantoni12@gmail.com ORCID No: 0000-0001-9336-3780

3 Lecturer, Physics Education Department, Universitas Jambi, Indonesia, Email: dianrasmi91@gmail.com ORCID No:

4 Lecturer, Physics Education Department, Universitas Jambi, Indonesia, Email: kurniawan_wawan@unja.ac.id ORCID No: 0000-0002-0608-1548

5 Dr, Universitas Islam Negeri Sulthan Thaha Saifuddin Jambi, Indonesia, Email: iskandar@uinjambi.ac.id ORCID No: 0000-0002-9912-8527 
knowledge is obtained from preschool education, which is the first place where students' social relationships are built on formal roofs and is an important place in student life (Ozturk \& Tortop, 2019).

Understanding the concept of physics is the foundation for building physics problem-solving skills which when already understand the concept, can be used to develop the ability to solve the problems (Lakuntu et al. 2017). Understanding the basic concepts and relationships between concepts, and able to use the concept to solve the problem is one of the objectives to be achieved in the study of physics and one of the ways to achieve such success is to please physics (Docktor \& Jose, 2014; Alia et al. 2017).

According to Ngoi \& Vendracek (2004), the emphasis on understanding student concepts needs to be built in building a curriculum. In understanding the concept three areas are the focus in the study of misconceptions, resource theory or piece of knowledge and ontological (Docktor \& Jose, 2014). Most studies were done that are related to misconceptions (Sutopo, 2016), and a little study on the resource theory or Knowledge in the Piece "view (Sabo et al., 2016).

"Knowledge in Piece"view or Resource Theory shows that students who fail to resolve the issue do not mean they do not understand the concept, but they may have the right knowledge, but they failed to turn in the context of true knowledge or knowledge they have still be bits pieces of knowledge (Docktor \& Jose, 2014). This is because success in activating the resource is highly dependent on context (Hammer, 2000; Docktor and Jose, 2014), because of their knowledge is still in pieces and analyzed within the framework of knowledge in chunks (DiSessa et al. 1998; Jelicic et al. 2017).

The concept of direct current electricity is an important study in the fields of physics and engineering. This material is classified as complex because it examines the concept of Ohm's law, rules of series and parallel circuits, Kirchoff's law, energy and electric power (Riantoni, 2017). For example, according to the study of Riantoni et al. (2016) revealed that many students still have difficulty in understanding related to current, voltage, resistance, circuit diagrams and electrical power in a simple circuit. Nugraha et al. (2013) also revealed that students' conceptions of direct current electric circuits were still low, especially those related to the relationship in the circuit, Kirchoff's Law I and electric fields and the discovery of misconceptions in direct current electric circuits including (a) the existence of an electric current flowing in the circuit even though the switch has been disconnected, (b) the magnitude of the current passing through the resistance in the series and parallel circuit is the same, and (c) the electric current flowing in the parallel circuit at all points is the same.

Study-related to direct current electricity is mostly based on misconceptions, but less based on Knowledge in Piece "view or resource theory. Some study on Knowledge in Piece "view or resource theory is more focused on understanding the concepts of rotational dynamics (Rahmawati et al. 2017) and the concept of energy (Sabo et al. 2016). Therefore, a study of understanding student concepts based on the Knowledge in Piece "view needs to be done.

\section{Research Problem}

Based on the introduction, the formulation of the problem in this article is "how is the understanding of students' concepts related to direct current electricity based on knowledge in pieces theory?

\section{Method}

\section{Research Design}

This study is a mixed-method study with explanatory model design (Creswell \& Clark, 2007). The study design used in this study is shown in Figure 1.

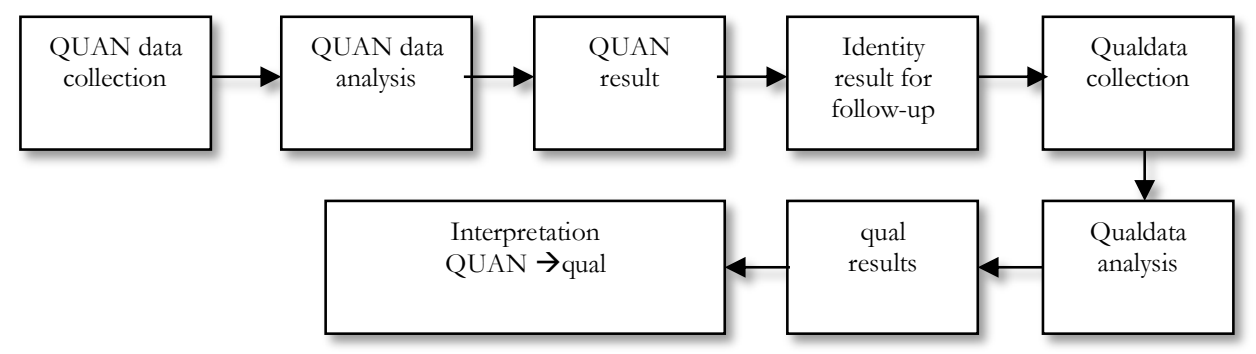

Figure 1.

Explanatory Design: Follow-up Explanation Model (QUAN Emphasized) 


\section{Participants}

The subjects of this study were S-1 physics education students at Jambi University, Indonesian. The total population in this study was 456 students who had passed a basic physics course and basic electronics, with a total sample of selected 148 (43 male and 105 female) physics education students. In addition, research subjects are around 19 to 21 years old. The sample selection is done by a purposive sampling technique (Creswell \& Clark, 2007). Sampling for the test was taken based on consideration of the students' basic physics scores. While the interview sample was chosen based on unclear student exam answers.

\section{Data Collection and Instrument}

The data in this study were obtained through tests or dissemination of student concept comprehension questions, which amounted to one multiple choice reasoned and interviewed item. Determining and Interpreting Resistive Electric Circuit Concept Test (DIRECT): The instrument used was developed to evaluate the conceptual understanding of high school students and early year students about electricity (Engelhardt \& Beichner, 2004). Before being used in the study, the items have passed the expert validation beforehand to find out the validity of the questions. Based on the results of expert validation, all questions were declared valid with some improvements according to the suggestions of the validator. After expert validation, the instrument is continued with field trials to determine empirical validity and reliability. The results of the analysis of 1 item understanding of the concept obtained instruments meet the requirements of validity with reliability is very good (Cronbach alfa coefficient 0.84 ). The test instrument is shown in Figure 2.
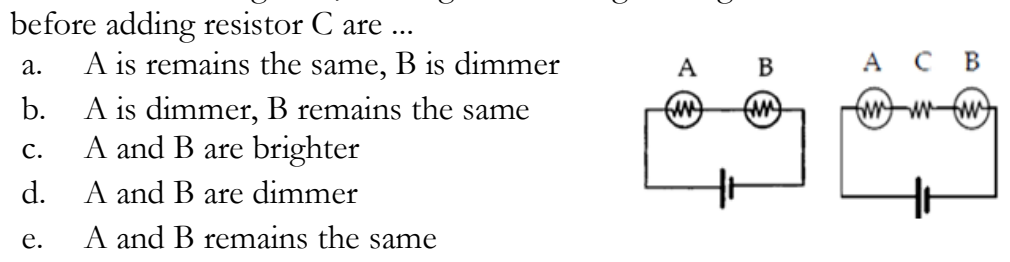

\section{Figure 2.}

Problem Items for Assessing Student Resource Activation on the Concept of Current Relationships, Potential Differences and Electric Resistance in Circuits (Ohm's Law)

After the test results were analyzed, the study continued with interviews. The interview guide contains questions that are asked to a group of students based on answers to the understanding of the concepts provided on the test. In the interview each student was asked to explain again how they process in getting answers during the test and confirm the answers that are not clear. The purpose of the interview is to confirm student answers that are still unclear and to explore deeper the types of approaches students use in solving dynamic electricity problems. An interview sheet guide is presented in Figure 3.

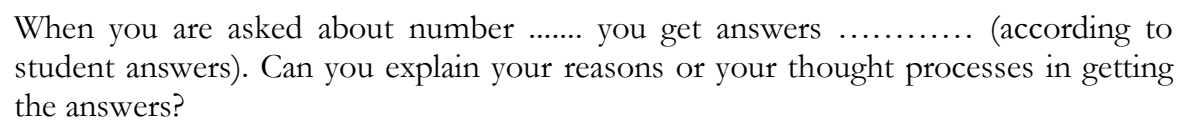

\section{Figure 3.}

Interview Question

\section{Data Analysis}

Data analysis techniques in this study were the results of tests and interviews were analyzed based on indicators to determine students' understanding of concepts. Indicators are arranged after answers from the student test results are obtained. This is because the indicator must be based on the activation of resources used by students in answering questions. Indicator will function to distinguish between students who are able to fully activate concepts and students who still understand concepts in the form of concept pieces. Students who have a good understanding of the concept and activation of the correct resource will be two possible forms of answers, namely (1) students answer with the reason of using the concept of electric power, (2) students answer with a complete explanation related to the state of current, resistance and voltage in the circuit in Figure 2. 
The data analysis steps are; (1) collecting data from test results, (2) after the data is collected, the data is grouped, and answers are coded based on the number of students who answer the same answers with the same type of answer categories. (3) Then the results of this test are tested and presented in the form of a percentage to map the understanding of each student related to direct current electricity Then the final step is to conclude the understanding of student concepts.

Qualitative data analysis of students' understanding of concepts was carried out based on interviews with student answers that were not clear in the test. The analysis process is done by reducing the data from the interviews through records that are adjusted to the results of quantitative data before the interview. This is done to obtain clearer and more complete data related to students' understanding of concepts. The results of the data reduction are encoded, where the coding process is carried out due to grouping students who understand the concepts. Coding is based on the criteria for the description of the answers and reasons of the students.

\section{Results and Discussion}

The problems given in this study aim to deny the understanding of the concept of prospective physics teacher students about Ohm's Law (See Figure 2). To answer these problems, students need to understand the basic concepts of the relationship between current, resistance and potential differences in an electrical circuit.

Table 1.

Distribution of Student Answers and Applied Concepts to Answer Problem

\begin{tabular}{|c|c|c|c|c|}
\hline Choice & $\mathbf{N}$ & Category & Applied Concepts & $\mathbf{N}$ \\
\hline \multirow{3}{*}{ A } & \multirow{3}{*}{$43(29 \%)$} & 1 & $\begin{array}{l}\text { The electric current that flows the voltage remains the } \\
\text { same as before and the resistor added or changing the } \\
\text { lamp after wards will fade }\end{array}$ & $20(13.5 \%)$ \\
\hline & & 2 & Electrical resistance will affect the brightness of the lamp & $1(0.7 \%)$ \\
\hline & & 3 & The electrical resistance affects only light B only & $22(14.8 \%)$ \\
\hline B & $\begin{array}{c}1 \\
(0.7 \%)\end{array}$ & 1 & $\begin{array}{l}\text { If an electrical resistance is added to light } \mathrm{A} \text { dims and } \mathrm{B} \\
\text { remains the same }\end{array}$ & $1(0.7 \%)$ \\
\hline $\mathrm{C}$ & $\begin{array}{c}1 \\
(0.7 \%)\end{array}$ & 1 & $\begin{array}{l}\text { Because the electric current is directly proportional to the } \\
\text { resistance }\end{array}$ & $1(0.7 \%)$ \\
\hline \multirow{6}{*}{$\mathrm{D}$} & \multirow{6}{*}{$\begin{array}{c}85 \\
(57.4 \%)\end{array}$} & 1 & $\begin{array}{l}\text { Both lights are dimmed due to the addition of electrical } \\
\text { resistance to the circuit }\end{array}$ & $47(31,8 \%)$ \\
\hline & & 2 & The more lights installed, the dimmer the lights will be & $2(1,3 \%)$ \\
\hline & & 3 & $\begin{array}{l}\text { Because lights A, B and C are series, that is the nature of } \\
\text { the current divider, when added resistance A and B fade }\end{array}$ & $24(16,2 \%)$ \\
\hline & & 4 & $\begin{array}{l}\text { Because the electrical resistance is large and the current is } \\
\text { the same }\end{array}$ & $2(1.3 \%)$ \\
\hline & & 5 & $\begin{array}{l}\text { When given a resistance the current flowing is smaller } \\
\text { than without resistance }\end{array}$ & $6(4 \%)$ \\
\hline & & 6 & Unclear & $4(2.7 \%)$ \\
\hline \multirow{4}{*}{$\mathrm{E}$} & \multirow{4}{*}{$\begin{array}{c}15 \\
(10.1 \%)\end{array}$} & 1 & $\begin{array}{l}\text { When the lamp is given resistance, the current flowing is } \\
\text { the same }\end{array}$ & $1(\% 0,7)$ \\
\hline & & 2 & $\begin{array}{l}\text { The greater is given, the smaller the current generated, } \\
\text { while the greater the resistance the greater the voltage } \\
\text { produced }\end{array}$ & $4(2,7 \%)$ \\
\hline & & 3 & Because it is a series & $9(6 \%)$ \\
\hline & & 4 & Unclear & $1(0.7 \%)$ \\
\hline No Answer & & & & $3(2 \%)$ \\
\hline
\end{tabular}

Based on the results of the study in (See Table 1), there were 85 (57.4\%) students who answered correctly (answer D) but there were 5 types of reasons categories obtained from 148 students, namely (1) Students thought that both lights dimmed due to the addition of obstacles in the circuit; (2) Students think that the more lights are installed, the 
more the lights will dim; (3) Students think that because lamps A, B, and C are series, that is, a current divider, when added resistance A and B fades; (4) Because the obstacles are large and the currents are the same; (5) When given a resistance the current flowing is smaller than without resistance. The fifth reason category is students who have the right activation of resources and the rest still do not fully understand the concept. The interesting thing found was that only $4 \%$ of students answered with the same answer in category 5 , the rest gave incorrect answers. The proof is 43 students (29\%) who answered answer A with 3 different categories of reasons. Furthermore, $0.7 \%$ of students gave answers $\mathrm{B}$ and $0.7 \%$ answered $\mathrm{C}$, and $10.1 \%$ answered $\mathrm{E}$ answers with 3 answer categories.

The number of students who are still not right in answering does not mean students do not understand the concept, but they only know the pieces of the concept. This can be seen in the answers of students who answered $\mathrm{D}$ for reasons of category 1. Students think that the two lights are dimmed due to the addition of obstacles in the circuit. The answer is correct, but students do not indicate specific reasons why the lights dim when given obstacles. The student conception is called an alternative conception. Alternative conceptions are conceptions that are not following generally accepted scientific understanding (Wenning, 2008; Ipek \& Calik, 2008). The students' conceptions can be right or wrong. Students should be able to give reasons based on the effects that occur on current and voltage if added resistance.

There are still many students who understand the concept in the form of pieces of concepts are also supported by one example of interview data as follows:

Lecturer : When you answer the question, in your answer sheet shows that the lights dim when added obstacles. Try to explain again from where you got such conclusions?

Student :If added resistance, the current automatically (lamp 1) changes, then the circuit becomes a series. If the series is the same, the current is the same.

Lecturer : :yes

Student : In my opinion, what causes dim lights is the voltage.

Lecturer : Is it only voltage?

Student $\quad$ :yes.

In the interview transcript it is very clear showing students' understanding of the concept of direct current electricity is not yet intact and is still in the form of pieces of knowledge. Students assume that only the magnitude of the voltage affects the light.

These results are consistent with the results of research conducted by Rahmawati et al. (2017) on the concept of rotational dynamics showing that the students' resources had not been coupled coherently so that the less dominant resource would be delayed to activate than the more dominant resource. In addition, research conducted by Singh (2010) also shows that many students do not have a complete understanding of the electrical circuit, such as a small error in determining the amount of electric current on the second side of a lamp in a series of which many students still assume a different magnitude.

Some errors experienced by students are also supported by previous studies related to direct current electric material, which shows that many students have difficulty in describing and interpreting circuit diagrams (Engelhardt \& Beichner, 2004; Kock, et al. 2014; Stetetzer et al. 2013) and confusion in understanding the concept of currents, potential differences, and obstacles (Engelhardt \& Beichner, 2004; Smith \& Kampent, 2011; Kock et al. 2014). Another mistake is that students argue that current and resistance are the main concepts, while stress is considered as a consequence of the current and not as a cause (Pfister, 2004; Smith \& Kampent, 2011). Besides, students use an incorrect model of the concept of electric current which thinks that the current will decrease when it passes through an obstacle (Kock et al. 2014; Engelhardt \& Beichner, 2004).

The interesting thing in this study is that of all the students' answers, none of the students applied the concepts of energy and electrical power in determining the brightness of lights. These results indicate that there is a fundamental error that is owned by students, namely not being able to understand the concepts of energy and electrical power which is the relationship between the concepts of current, voltage and resistance correctly. most students think that what causes light is electric current and students think that the light bulb closest to the positive pole of the battery will get more current than the others. This means that the light bulb that is closest to the positive battery will light brighter than the others. These results prove that students fail to use the right concepts in solving problems. According to the theory of misunderstanding, students who fail in solving problems are caused by the knowledge they have not in 
accordance with scientific concepts (Rahmawati et al. 2017; Clement, 1982). Whereas according to resource theory, students failing to solve problems does not mean that knowledge has errors but is not activated in the right context.

Based on the results of the study and data analysis, it can be concluded that the understanding of student concepts in direct current electric material is still not very good, this is indicated from the study data of only 6 people (4\%) of 148 students who can activate the concept properly and completely. The findings show that student understanding is still in the form of concept pieces. Students are not able to connect concepts properly. When asked about sub-material students have an understanding, but when the problem is given complete enough students are not able to connect every concept to the sub-material that they understand correctly.

\section{Limitations of Study}

Limitation in this study is that researchers have not collected data on all basic Physics material, but only focus on direct current electricity. In addition, the cause of the low ability of student resource activation has not been identified in depth.

\section{Recommendations}

For further studies, it is necessary to identify the understanding of student concepts with a "knowledge in piece" view on different physics materials, such as mechanics and thermodynamics. This is so that in the future can be the basis for determining appropriate learning techniques in learning physics. Based on these findings, the instructor is advised to provide real phenomena to students in teaching the concept of direct current resistive electrical Circuits. This can help students better understand the concept of direct current resistive electrical Circuits and can connect between concepts to solve the problems.

\section{Acknowledgements}

This study was supported by the Universitas Jambi at Indonesia. The Author Thank Physics Education Program who support and participate in this study.

\section{Biodata of the Authors}

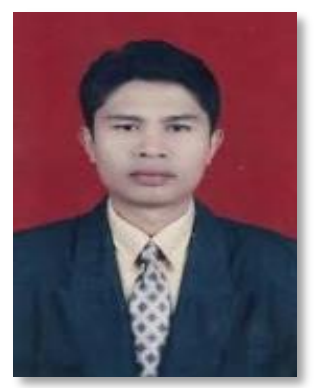

Nehru is an lecturer in physics Education Programs at Universitas Jambi. He taught Physics Courses in the Universitas Sumatera Utara and InstitutTeknologi Bandung, Indonesia. He is currently a Ph. D candidate in Sains Education at the Universitas Jambi. The Focuses Research are about learning and teaching Physics and Conceptual understanding. Affiliation: Physics Education Programs, Universitas Jambi, Indonesia Email: nehru@unja.ac.id SCOPUS ID: 57208577226 WoS Researcher ID : -ORCID ID: 0000-0002-1166-5732

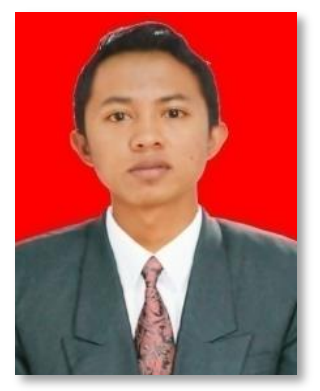

Cicyn Riantoni is an lecturer in physics Education Programs at Universitas Jambi. He taught Physics Courses in the Universitas Jambi and Universitas Negeri Malang, Indonesia. He is currently a Ph.D candidate in Sains Education at the Universitas Jambi. The Focuses Research are about Problem Solving In Physics and Physics Conceptual understanding. Affiliation: Physics Education Programs, Universitas Jambi, Indonesia. Email:cicynriantoni12@gmail.com SCOPUS ID: 57195058704

WoS Researcher ID:-ORCID ID: 0000-0001-9336-3780

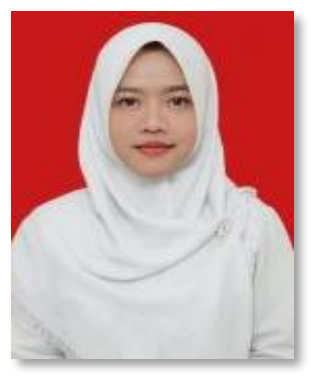

Dian Pertiwi Rasmi is an lecturer in physics Education Programs at Universitas Jambi. He taught Physics Courses in the Universitas Jambi and Universitas Negeri Jakarta, Indonesia. The Focuses Research are about Sains Technology, Enginering and Mathematics (STEM). Affiliation: Physics Education Programs, Universitas Jambi. Email: dianrasmi91@gmail.com SCOPUS ID:-WoS Researcher ID : -ORCID ID: - 


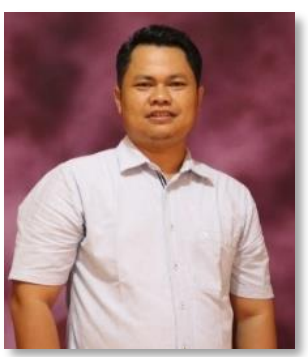

Wawan Kurniawan is an lecturer in physics Education Programs at Universitas Jambi. He taught Physics Courses in the Universitas Sumatera Utara and Universitas Gajah Mada, Indonesia. He is currently a Ph. D candidate in Sains Education at the Universitas Jambi. The Focuses Research are about Computational Physics and Artificial Intelegent
Affiliation:
Physics Education
Programs,
Universitas Jambi.
Email:

kurniawan_wawan@unja.ac.id SCOPUS ID: 57191543442

WoS Researcher ID :-ORCID ID: 0000-0002-0608-1548

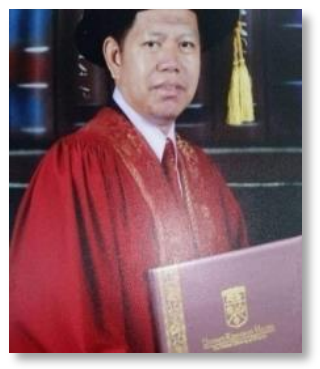

Iskandar is an Dean of Science and Technology Faculty at UIN Sulthan Thaha Saifuddin Jambi. He taught P.hD about Psychology Education in the Universitas Kebangsaan Malaysia and Universitas Gajah Mada, Indonesia.

Affiliation: Universitas Sulthan Thaha Saifuddin Jambi, Indonesia. Email: iskandar@uinjambi.ac.id SCOPUS ID:57210653651

WoS Researcher ID: -ORCID ID: 0000-0002-9912-8527

\section{References}

Alia, N., Sunarno, W., Aminah., N.S. (2017). Development of Physics Modules in Dynamic Electric Material Based on Science Process Skills (KPS) to Improve Critical Thinking Ability in High School / Ma Class X Students. Jurnal Inkuiri, 6(1), 111-120. Creswell, J \& Clark, V.P. (2007). Designing and Conducting Mix Methods Study. United States America: Sage Publication.

Cokc, D. M. (2012). Representation Use and Strategy Choice in Physics Problem. Physics Review Special Topics- Physics Education Study, 8(020117), 1-15.

Clement, J. (1982). Students' preconceptions in introductory mechanics. American Journal of Physics, 50(1), 66-71.

Dewi S.Z \& Andi S. (2016). Implementation of Predict, Discuss, Explain, Observe, Discuss, Explain (Pdeode) Strategies in Elementary School Science Learning To Improve Understanding of Concepts and Reduce Quantities of Students Who Misconceptions on Material Changes in Objects in Class V, Journal of Basic Education, 8(1), 12-21.

DiSessa, A. A. (1993). Toward an Epistemology of Physics. Cognition and Instruction, 10 (2 \& 3),105-225.

Docktor, J.L \& Mestre, J.P. (2014). Synthesis of Discipline-Based Education Study In Physics. Physics Review Special Topics- Physics Education Study, 10(020119), 1-58.

Engelhardt, P.V \& Beichner, J.R. (2004). Students' Understanding of Direct Current Resistive Electrical Circuits. American Journal of Physics, 72(1), 98-115.

Elisa., Mardiyah, A., \& Ariaji, R. (2017). Increased Understanding of Physics Concepts and Student Activities Through Phet Simulation. Jurnal Penelitian Tindakan Kelas dan Pengembangan Pembelajaran. 1(1), 15-20.

Hammer, D. (2000). Student Resources for Learning Introductory Physics. American Journal of Physics, 68(7), 52-59.

Ipek, H. \& Calik, M. (2008). Combining Different Conceptual Change Methods within Four-Step Constructivist Teaching Model: A Sample Teaching of Series and Parallel Circuits. International Journal of Environmental \& Science Education, 3(3), $143-153$.

Jelicic, K., Plainic, M., \&Planinsic, G. (2017). Analysing High School Students' Reasoning about Electromagnetic Induction, Physical Review Physics Education Study, 13(1), 1-18.

Kalayc1, S., \& Çoşkun, M. (2020). Determination of Gifted/Talented Students' Interest in Science Subjects in Terms of Some Variables. Journal of Gifted Education and Creativity, 7(1), 1-12.

Lakuntu, J. K., Werdhiana, I.K., \& Muslimin. (2017). Application of Conceptual Understanding Learning Model Procedures Using Experimental Methods for Understanding Newton's Law Concepts in Class X Students of SMA Negeri 1 Palu, Jurnal Pendidikan Fisika Tadulako Online (JPFT), 5(1), 48-51.

Mosik \& Maulana, P. (2010). Usaha Mengurangi Terjadinya Miskonsepsi Fisika Melalui Pembelajaran Dengan Pendekatan Konflik Kognitif. Jurnal Pendidikan Fisika Indonesia, 6, 98-103.

Mohammad, A., \& Asrori, M. (2014). Metodologi dan Aplikasi Riset Pendidikan. Jakarta: BumiAksara.

Nugraha, A., Werdhiana, I.K., \& I Wayan, D. (2013). Deskripsi Konsepsi Siswa SMA Tentang Rangkaian Listrik Arus Searah (Description of High School Students' Conception of Direct Current Circuits). Jurnal Pendidikan Fisika Tadulako (JPFT), 1(3).

Ngoi, M., \& Vondracek, M. (2004). Working with Gifted Science Students in Public Hight School Environment: One School Approach. The Journal of Secondary Gifted Education, 15(4), 141- 147.

Oktalia, Y., Sakti, I., \& Hamdani, D. (2017). Pengaruh Minat dan Motivasi Pada Penerapan Model Discoveri Berbantuan Media Animasi Terhadap Hasil Belajar Fisika di SMA Negeri 4 Kota Bengkulu (The Effect of Interest and Motivation on the Application of the Discovery Model Assisted by Animation Media Against Physics Learning Outcomes in SMA Negeri 4 Bengkulu City). Jurnal Imu dan Pembelajaran Fisika, 1(1), 87-95.

Ozturk, F.D., \& Tortop, H. S. (2019). Investigation of the relationship between attachment styles and social skill level and play behavior of preschool 4-6 years old children. Journal of Gifted Education and Creativity, 6(2), 75-85.

Pfister, H. 2004. Illustrating Electric Circuit Concept with the Glitter Circuit. The Physics Teacher, 42 (6), $359-363$.

Rahmawati, I., Sutopo., Zulaikah, S. (2017). Analysis of Students' Difficulties About Rotational Dynamics Based on Resource Theory. Jurnal Pendidikan IP A Indonesia, 6(1), 95-102. 
Riantoni, C., Yuliati, L., \& Mufti, N. (2016). Identify Student Difficulties in Understanding Dynamic Electricity. Proceedings of the Indonesian National Science Education Seminar, (Postgraduate State University of Malang, Malang), pp. 112-121

Riantoni, C., Yuliati, L., Mufti, N., \& Nehru. (2017). Problem Solving Approach in Electrical Energy and Power on Students As Physics Teacher Candidates. Indonesian Journal of Science Education, 6(1), 1-11.

Sabo, H. C., Goodhew, L. M., \& Robertson, A. D. (2016). University Student Conceptual Resources for Understanding Energy. Physical Review Physics Education Study, 12(1), 1-28.

Singh, V. (2010). The electron runaround: understanding electric circuit basics throug a classroom activity. The Physics Teacher, 48, 309-311.

Sutopo. (2016). Students' Understanding of Fundamental Concepts of Mechanical Wave. Jurnal Pendidikan Fisika Indonesia, 12(1), 41-53.

Stetetzer, M.R., Kampen, P.V., Shaffer, P. S \& McDermott, L. C. (2013). New Insights into Student Understanding of Complete Circuits And The Conservation Of Current. American Journal of Physics, 81(2), 134-143.

Smith, D.V \& Kampen, P.V. 2011. Teaching Electric Circuits with Multiple Batteries: A Qualitative Approach. Physics Review Special Topics- Physics Education Study, 7(010115), 1-10.

Vreeland, P. (2002). Analyzing Simple Circuits. The Physics Teacher, 40(99), 99-100.

Wenning, C.J. 2008. Dealing More Effectively with Alternative Conception in Science. Journal Physics Teacher Education, 5(1), 1119.

Yuberti, Y., Rantika, J., Irwandani, I., \& Prasetiyo, A.E. (2019). The Effect of Instructional Design Based on Learning Cycle 7E Model with Mind Map Technique to the Students' Critical Thinking Skills. Journal of Gifted Education and Creativity, 6(3), 175191. 